\title{
Selection for Grain Yield in Bread Wheat (Triticum aestivum L.) under Normal Irrigation and Water Stress Conditions
}

\author{
Koubisy, Y.S.I. \\ Wheat Res. Dep., Field Crops Res. Inst., ARC, Giza, Egypt. \\ Received on: $23 / 2 / 2020$ \\ Accepted for publication on: 3/3/2020
}

\begin{abstract}
The present research was carried out through the three successive seasons from 2016/17 to 2018/19 at Shandaweel Agric. Res. Stat., Sohag Governorate, Egypt, to study the efficiency of pedigree selection in improving grain yield in bread wheat under normal and drought conditions. Two cycles of selection were completed under each condition for $\mathrm{F}_{2}$ to $\mathrm{F}_{4}$-generations. At the last season, the selected $\mathrm{F}_{4}$ families under each condition were evaluated under both conditions. The genotypic variance was slightly less than the phenotypic variance under both conditions and generally decreased from the base population $\left(F_{2}\right)$ to $F_{4^{-}}$ generation. Broad-sense heritability was 78.33 and $71.93 \%$ under normal irrigation compared to 86.44 and $58.48 \%$ under water stress after cycle 1 and 2 , respectively. The realized heritability was 29.93 and $90.88 \%$ under normal irrigation compared to 36.47 and $89.48 \%$ under water deficit after cycle 1 and 2, respectively. The average observed gains of normal irrigation selections were 40.29 and $66.34 \%$ from bulk sample and 29.92 and $35.27 \%$ from the better parent, while the average observed gains of water stress selections were 32.89 and $40.42 \%$ from bulk sample and 23.07 and $14.19 \%$ from the better parent, when evaluation practiced under normal irrigation and water stress, respectively. The results indicated that the synergistic selection was better than antagonistic selection in changing the mean and decreased the sensitivity. Grain yield/plant revealed positive and high phenotypic correlation with each of plant height, biological yield/plant, number of spikes/plant and number of kernels/spike under normal irrigation and water stress, and 100-kernel weight under water stress in the base population and after two cycle of selection for grain yield/plant.
\end{abstract}

Keywords: Pedigree selection, selection response, drought susceptibility, wheat.

\section{Introduction}

Wheat is considered the most important cereal crop in Egypt. The cultivated area in Egypt reached 3.1 million feddans in 2018/2019 growing season, with an average yield of $18.00 \mathrm{ardab} /$ feddan, and the total production was about 9.1 million tons (Economic Affairs Annual Report, 2018). Therefore, great efforts of wheat breeders and geneticists must be continue to increase the productivity of unit area to decrease the gap between the production and con- sumption. Expanding the cultivated area of wheat is only possible in the new reclaimed lands, where water stress is the main obstacle. Drought is recurring condition of abnormally dry weather leading to moisture stress for plants. Stress depends on number of factors including degree of moisture deficiency, its duration and spatial spread. Plants usually adapted to drought through three major mechanisms, namely, escape, avoidance and resistance. Although the genetic and physiological bases of these mecha- 
nisms have not been established precisely, they have been indirectly exploited by plant breeders in developing drought tolerance cultivars.

Drought is one of the main abiotic stresses and an important factor for reducing yield of cultivated plants in semi arid agricultural lands (Amin-Alim, 2011). Therefore, breeding programs should work to develop high yielding cultivars over a wide range of stress and non-stress environments. The efficiency of a breeding program for drought tolerance depends largely on the selection criteria and selection method used to achieve genetic improvement through selection, in addition to the complexity of drought itself (Passioura, 2007). Pedigree selection can be used to identify superior genotypes for grain yield in cultivars development program. Several workers reported that the pedigree selection represent the most effective method in improving grain yield (Kheiralla et al. 1993; Ismail, 1995; Tammam et al. 2004; Ahmed, 2006; Ali, 2011; Mahdy et al. 2012 and Abd El-Rady, 2017). Breeding for drought tolerance should focus on increasing genetic variance and choosing a selection environment that is representative of the target environment. Some researchers believe in selection under favorable conditions (Betran et al., 2003), others prefer selection in a target stress condition (Rathjen, 1994), while other yet have chosen a mid-point and believe in selection under both favorable and stress conditions
(Byrne et al., 1995). Jinks and Connolly (1973 and 1975), Jinks and Pooni (1982) and Falconer (1990) indicated that, environmental sensitivity was reduced if selection and environment effects were in opposite direction, while sensitivity was increased if selection and environment effects were in the same direction. Correlation coefficient is an important statistical tool which can help wheat's breeder to select of high yield genotypes because it provides a better understanding of the association of different traits with grain yield.

The objectives of this present research were to study the relative merits of pedigree selection for grain yield under normal irrigation and water stress conditions, the sensitivity of the selected lines to deficit irrigation and the correlation coefficient of grain yield and its components in the base population and cycle two of selection under normal irrigation and water stress.

\section{Materials and Methods}

This study was carried out at the Experimental Farm of Shandaweel Agric. Res. Station, ARC., Egypt, during the three successive seasons, i.e. 2016/2017, 2017/2018 and 2018/2019. The base population was the $\mathrm{F}_{2^{-}}$population of the cross (Giza $171 \times$ Gemmiza 11). Two cycles of pedigree selection were achieved under normal irrigation and water stress and evaluated under both environments in $\mathrm{F}_{4}$-generation. The pedigree of the parents is presented in Table 1.

Table 1. The pedigree of the parents of the wheat population.

\begin{tabular}{|l|l|}
\hline \multicolumn{1}{|c|}{ Parent } & \multicolumn{1}{c|}{ Pedigree and selection history } \\
\hline Giza 171 & Gemmiza / Sakha 93 \\
S.6-1GZ-4GZ-1GZ-2GZ-0S \\
\hline Gemmiza 11 & $\begin{array}{l}\text { BOW"S"/KVZ"S"/7C/SERI-82/3/GIZA 168/SAKHA 61 } \\
\text { GM7892-2MG-1MG-2MG-1MG-0MG }\end{array}$ \\
\hline
\end{tabular}


In 2016/2017 season $500 \quad \mathrm{~F}_{2}-$ individual plants were grown in nonreplicated plots under normal irrigation and water stress. The experiment under normal irrigation was grown in supplemental water applied regularly as recommended, while the experiment under water stress did not receive any irrigation after the second irrigation (planting irrigation and two irrigations throughout the growing season). Each plot consisted of 25 rows $2 \mathrm{~m}$ long, $30 \mathrm{~cm}$ apart and 10 $\mathrm{cm}$ between plants within rows for the $\mathrm{F}_{2}$ population. After maturity, plants were individually harvested and threshed and data were recorded on all guarded plants.

In $2017 / 2018$ season $\quad\left(\mathrm{F}_{3^{-}}\right.$ generation); $30 \mathrm{~F}_{3}$ families, original parents and $\mathrm{F}_{3}$ bulked random sample (a mixture of equal number of grains from each plant to represent the generation mean) were sown in the two field experiments using a randomized complete block design with three replications. Each plot consisted of a single row $3 \mathrm{~m}$ long, $30 \mathrm{~cm}$ apart and $10 \mathrm{~cm}$ between grains within row. The recommended cultural practices for wheat production were adopted throughout the growing season in the two experiments. At the end of the season, separate analysis of variance of the two treatments was applied on a plot mean basis. The best 10 high yielding plants from the best 10 high yielding families were saved to give the $\mathrm{F}_{3}$ families in each environment.

In $2018 / 2019$ season $\left(\mathrm{F}_{4^{-}}\right.$ generation); the 10 high yielding $\mathrm{F}_{4}$ families selected under normal irrigation, the 10 high yielding $\mathrm{F}_{4}$ families selected under water stress environment, the two parents and the bulk sample were evaluated under both environments. Data were recorded on ten guarded plants from each family. The studied traits were; days to heading (DH), days to maturity (DM), plant height $(\mathrm{PH}, \mathrm{cm})$, number of spikes/plant (NS/P), number of kernels/spike (NK/S), 100-kernel weight $(100-\mathrm{KW}, \mathrm{g})$, grain yield/plant (GY/P, g) and biological yield/plant (BY/P, g).

\section{Statistical analysis:}

Data were subjected to proper statistical analysis according to Steel and Torrie (1980). Two analysis of variance were applied, the first was for (families, parents and bulk sample), and the second was for the selected families to calculate heritability, genotypic and phenotypic coefficient of variations. Genotypes means were compared using Revised Least Significant Differences (RLSD) test at 5 and $1 \%$ level of probability, according to El-Rawi and Khalafala (1980). The phenotypic $\left(\sigma^{2} p\right)$ and genotypic $\left(\sigma^{2} \mathrm{~g}\right)$ variances and heritability in broad sense (H\%) were calculated according to Walker (1960). The phenotypic (PCV\%) and genotypic (GCV\%) coefficients of variability were calculated as outlined by Burton (1952), Realized heritability $\mathrm{h}^{2}=\mathrm{R} / \mathrm{S}$ was calculated according to Falconer (1989); where $\mathrm{R}=$ response to selection and $\mathrm{S}=$ selection differential. Drought susceptibility index (DSI) was computed according to the method of Fischer and Maurer (1978). The sensitivity and relative merits of selected families were assessed as described by Falconer (1990). The relative merits is expressed as the ratio change of mean 
by antagonistic selection / change of mean by synergistic selection.

The phenotypic correlation coefficients via base population $\left(\mathrm{F}_{2}\right)$ and the second cycle of selection $\left(\mathrm{F}_{4}\right)$ were calculated among the studied traits as outlined by Al- Jibouri et al. (1958), as follows: Phenotypic correlation $\mathrm{rp}_{\mathrm{xy}}=\operatorname{cov} \mathrm{p}_{\mathrm{xy}} /\left(\sigma \mathrm{p}_{\mathrm{x}} \cdot \sigma \mathrm{p}_{\mathrm{y}}\right)$.

\section{Results and Discussion}

1- Description of the base population; season 2016/2017

The base population used in this study was the $\mathrm{F}_{2}$-generation of the cross between Giza 171 x Gemmiza 11 which were completed using 500 $F_{2}$ plants under normal irrigation and water stress conditions. Data in Table 2 show the average, range and phenotypic variance of studied traits of $\mathrm{F}_{2}$ generation under normal irrigation and water stress conditions.

The average of grain yield/plant, plant height, number of spikes/plant, number of kernels/spike, 100-kernel weight and biological yield/plant under normal irrigation were, $25.31 \mathrm{gm}$, $114.20 \mathrm{~cm}, 10.18 \mathrm{~S} / \mathrm{P}, 49.13 \mathrm{~K} / \mathrm{S}$, $5.43 \mathrm{gm}$ and 245.24 . Whereas, these were $21.25 \mathrm{gm}, 113.38 \mathrm{~cm}, 8.48 \mathrm{~s} / \mathrm{p}$, $47.34 \mathrm{k} / \mathrm{s}, 5.21 \mathrm{gm}$ and $69.22 \mathrm{gm}$ under water stress for the same previous traits, respectively.

Results of the phenotypic correlation coefficient among all possible pairs of the studied traits in the $F_{2}$ population (Table 3) show positive and high phenotypic correlation between grain yield/plant and each of plant height (0.258 and 0.245), number of spikes/plant (0.761 and 0.779), number of kernels/spike $(0.633$ and $0.620), 100$-kernel weight $(0.179$ and $0.186)$, biological yield/plant $(0.850$ and 0.808 ) under normal irrigation and water stress environments, respectively. These results, indicated that selection for high grain yield/plant could increase these traits. Number of spikes/plant possessed positive and high phenotypic correlation with plant height, biological yield/plant and number of kernels/spike under both environments. Moreover, number of kernels/spike possessed positive and high phenotypic correlation with plant height and biological yield/plant under both environments, while it was negative and high significant with 100-kernel weight $(-0.196)$ under normal irrigation.

\section{Phenotypic selection for grain yield/plant}

2.1. Variability and heritability estimates:

The analysis of variance (Table 4) indicated highly significant differences among the $F_{3}$ and $F_{4}$ families for all studied traits under normal and drought environments. These results indicated the presence of variability for further cycles of selection. Similar results were obtained by Ali (2011), Mahdy (2012), Ahmed et al. (2014), Salous et al. (2014), Soliman et al. (2015) and Abd El-Rady (2017). 
Table 2. The range, mean values and phenotypic variance $\left(\sigma^{2} \mathrm{ph}\right)$ of the $F_{2}$ population of the studied traits under normal irrigation and water stress conditions; Season 2016/2017.

\begin{tabular}{|c|c|c|c|c|c|c|}
\hline \multirow[b]{2}{*}{ Trait } & \multicolumn{3}{|c|}{ Normal irrigation } & \multicolumn{3}{|c|}{ Water stress } \\
\hline & Range & Mean \pm S.E & $\begin{array}{l}\text { Phenotypic } \\
\text { Variance }\end{array}$ & Range & $\begin{array}{l}\text { Mean } \pm \\
\text { S.E }\end{array}$ & $\begin{array}{c}\text { Phenotypic } \\
\text { Variance }\end{array}$ \\
\hline $\begin{array}{c}\text { Grain yield /plant, } \\
\text { gm }\end{array}$ & $\begin{array}{l}8.60- \\
46.52\end{array}$ & $\begin{array}{c}25.31 \pm \\
0.52\end{array}$ & 80.90 & $\begin{array}{l}5.62- \\
38.96\end{array}$ & $\begin{array}{c}21.25 \pm \\
0.48\end{array}$ & 70.22 \\
\hline Plant height, cm & $\begin{array}{c}103.00- \\
130.0\end{array}$ & $\begin{array}{c}114.20 \pm \\
0.29\end{array}$ & 24.55 & $\begin{array}{c}88.00- \\
121.0\end{array}$ & $\begin{array}{c}113.38 \pm \\
0.27\end{array}$ & 24.61 \\
\hline No. of spikes/plant & $\begin{array}{l}5.00- \\
19.00\end{array}$ & $\begin{array}{c}10.18 \pm \\
0.15\end{array}$ & 6.70 & $\begin{array}{l}3.00- \\
15.00\end{array}$ & $\begin{array}{c}8.48 \pm \\
0.14\end{array}$ & 7.02 \\
\hline $\begin{array}{l}\text { No. of ker- } \\
\text { nels/spike }\end{array}$ & $\begin{array}{c}26.59- \\
82.00\end{array}$ & $\begin{array}{c}49.13 \pm \\
0.67\end{array}$ & 135.98 & $\begin{array}{c}16.15- \\
68.00\end{array}$ & $\begin{array}{c}47.34 \pm \\
0.81\end{array}$ & 195.67 \\
\hline $\begin{array}{c}\text { 100-kernel weight, } \\
\text { gm }\end{array}$ & $\begin{array}{c}3.64- \\
7.00\end{array}$ & $5.43 \pm 0.03$ & 0.29 & $\begin{array}{l}3.45- \\
6.26\end{array}$ & $\begin{array}{c}5.21 \pm \\
0.02\end{array}$ & 0.14 \\
\hline $\begin{array}{c}\text { Biological } \\
\text { yield/plant, gm }\end{array}$ & $\begin{array}{l}33.00- \\
174.00\end{array}$ & $\begin{array}{c}80.84 \pm \\
1.57\end{array}$ & 245.23 & $\begin{array}{c}24.20- \\
150.0\end{array}$ & $\begin{array}{l}69.22 \pm \\
1.69\end{array}$ & 320.00 \\
\hline
\end{tabular}

Table 3. phenotypic correlation among the studied traits in the $F_{2}$ generation under normal irrigation (above diagonal) and water stress conditions (below diagonal).

\begin{tabular}{|c|c|c|c|c|c|c|}
\hline Trait & PH & NS/P & NK/S & $\mathbf{1 0 0 - K W}$ & $\mathbf{G Y / P}$ & $\mathbf{B Y / P}$ \\
\hline PH & -- & $0.150^{* *}$ & $0.221^{* *}$ & $0.110^{*}$ & $0.258^{* *}$ & $0.303^{* *}$ \\
\hline NS/P & $0.219^{* *}$ & -- & $0.122^{* *}$ & 0.042 & $0.761^{* *}$ & $0.873^{* *}$ \\
\hline NK/S & $0.126^{* *}$ & $0.106^{*}$ & -- & $-0.196^{* *}$ & $0.633^{* *}$ & $0.358^{* *}$ \\
\hline $100-\mathrm{KW}$ & $0.141^{* *}$ & -0.001 & 0.042 & -- & $0.179^{* *}$ & $0.168^{* *}$ \\
\hline GY/P & $0.245^{* *}$ & $0.779^{* *}$ & $0.620^{* *}$ & $0.186^{* *}$ & -- & $0.850^{* *}$ \\
\hline BY/P & $0.250^{* *}$ & $0.853^{* *}$ & $0.345^{* *}$ & $0.112^{*}$ & $0.808^{* *}$ & -- \\
\hline
\end{tabular}

The effect of selection for two cycles on variability and heritability estimates of grain yield/ plant is shown in Table 5. The phenotypic and genotypic variances in grain yield/ plant were high in the $\mathrm{F}_{2}$ generation under both normal and water stress conditions and dropped rapidly after cycle one $\left(\mathrm{C}_{1}\right)$ and cycle two $\left(\mathrm{C}_{2}\right)$. This may be due to the increase of homozygosity in the $\mathrm{F}_{4}$ generation. The phenotypic and genotypic variances under normal irrigation were $87.78,8.81$ and $6.36 \%$ and 69.53 , 6.98 and 6.95 than under water stress 87.64, 5.44 and 10.58 and 85.70, 4.70 and 6.19 in $\mathrm{C}_{0}, \mathrm{C}_{1}$ and $\mathrm{C}_{3}$, respectively. The phenotypic (P.C.V.\%) and genotypic (G.C.V.\%) coefficient of variability under normal irrigation were 36.53 and $32.50 \%$ for grain yield/plant in the base population and decreased to 20.83 and $18.43 \%$ after $\mathrm{C}_{1}$ and to 10.75 and $9.11 \%$ after $\mathrm{C}_{2}$. Likewise, the phenotypic and genotypic coefficient of variability under water stress showed the same trend. The P.C.V.\% and G.C.V.\% under water stress were very close to those under normal irrigation. The GCV\% was slightly less than the PCV\% under both environments. The close estimates of phenotypic and genotypic variability resulted in high estimates of broad sense heritability in the two cycle of selection. It is of interest to note that heritability estimates for grain yield/plant were 79.20 and $87.77 \%$ in the base population $\left(\mathrm{F}_{2}\right)$ and decreased to 78.33 and $86.44 \%$ 
after $\mathrm{C}_{1}$ and 71.93 and $58.48 \%$ after $\mathrm{C}_{2}$ under normal irrigation and water stress, respectively. This could be due to the decrease in genotypic variance due to selection.

Table 4. Mean squares for families selected for high grain yield/plant and correlated traits in $F_{3}$ and $F_{4}$ generations under normal irrigation $(N)$ and water stress (D) conditions.

\begin{tabular}{|c|c|c|c|c|c|c|c|c|c|c|c|}
\hline \multirow{2}{*}{$\stackrel{\Xi}{\Xi}$} & \multirow{2}{*}{$\underset{\mid=1}{\grave{\lambda}}$} & \multirow{2}{*}{ S. O. V. } & \multirow{2}{*}{ d.f } & $\begin{array}{l}\text { Selection } \\
\text { criterion }\end{array}$ & \multicolumn{7}{|c|}{ Correlated traits } \\
\hline & & & & GY/P & DH & DM & PH & $\mathbf{N S} / \mathbf{P}$ & NK/S & $100 \mathrm{KW}$ & $\mathbf{B Y} / \mathbf{P}$ \\
\hline \multirow{6}{*}{$\mathbf{F}_{3}$} & \multirow{3}{*}{$\mathbf{N}$} & Rep. & 2 & 7.16 & 3.90 & 46.34 & 155.45 & 0.32 & 0.32 & 0.007 & 92.61 \\
\hline & & Families & 29 & $26.42 * *$ & $32.05 * *$ & $12.34 * *$ & $52.98 * *$ & $3.22 * *$ & $80.07 * *$ & $0.18 * *$ & $245.75 * *$ \\
\hline & & Error & 58 & 5.73 & 2.22 & 4.97 & 15.11 & 0.64 & 27.29 & 0.090 & 87.81 \\
\hline & \multirow{3}{*}{ D } & Rep. & 2 & 24.00 & 0.08 & 4.88 & 26.72 & 4.07 & 13.63 & 0.005 & 637.63 \\
\hline & & Families & 29 & $16.33 * *$ & $22.90 * *$ & $13.13 * *$ & $69.34 * *$ & $2.50 * *$ & $80.24 * *$ & $0.24 * *$ & $267.60 * *$ \\
\hline & & Error & 58 & 2.22 & 2.83 & 1.52 & 8.23 & 0.55 & 15.01 & 0.05 & 52.53 \\
\hline \multirow{6}{*}{$\mathbf{F}_{4}$} & \multirow{3}{*}{$\mathbf{N}$} & Rep. & 2 & 11.69 & 12.07 & 15.35 & 28.27 & 0.36 & 29.80 & 0.082 & 32.20 \\
\hline & & Families & 19 & $29.00 * *$ & $34.96 * *$ & $29.62 * *$ & $25.93 * *$ & $3.37 * *$ & $24.05 * *$ & $0.231 * *$ & $434.13 * *$ \\
\hline & & Error & 38 & 8.14 & 2.86 & 2.82 & 12.23 & 1.03 & 9.52 & 0.085 & 136.47 \\
\hline & \multirow{3}{*}{ D } & Rep. & 2 & 10.03 & 8.55 & 2.07 & 144.96 & 1.73 & 16.18 & 0.87 & 518.00 \\
\hline & & Families & 19 & $31.73 * *$ & $17.28 * *$ & $7.66^{* *}$ & $34.09 * *$ & $2.16^{* *}$ & $67.62 * *$ & $0.276^{* *}$ & $276.69 * *$ \\
\hline & & Error & 38 & 13.172 & 1.954 & 2.926 & 12.712 & 1.066 & 24.312 & 0.139 & 114.937 \\
\hline
\end{tabular}

Table 5. Variability and heritability estimates of grain yield/plant after two cycles of selection under normal irrigation $(\mathrm{N})$ and water stress $(\mathrm{D})$ conditions.

\begin{tabular}{|c|c|c|c|c|c|c|c|c|c|c|c|c|}
\hline \multirow{2}{*}{$\begin{array}{c}\text { Selection } \\
\text { cycle }\end{array}$} & \multicolumn{2}{|c|}{$\boldsymbol{\sigma}_{\mathbf{p}}^{\mathbf{2}}$} & \multicolumn{2}{|c|}{$\boldsymbol{\sigma}^{\mathbf{2}} \mathbf{g}$} & \multicolumn{2}{c|}{ P.C.V. \% } & \multicolumn{2}{|c|}{ G.C.V. \% } & \multicolumn{2}{|c|}{$\mathbf{H} \%$} & \multicolumn{2}{c|}{$\begin{array}{c}\text { Realized } \\
\text { heritability }\end{array}$} \\
\cline { 2 - 13 } & $\mathbf{N}$ & $\mathbf{D}$ & $\mathbf{N}$ & $\mathbf{D}$ & $\mathbf{N}$ & $\mathbf{D}$ & $\mathbf{N}$ & $\mathbf{D}$ & $\mathbf{N}$ & $\mathbf{D}$ & $\mathbf{N}$ & $\mathbf{D}$ \\
\hline $\mathbf{F}_{\mathbf{2}}\left(\mathbf{C}_{\mathbf{0}}\right)$ & 87.78 & 87.64 & 69.53 & 85.70 & 36.53 & 45.11 & 32.50 & 42.23 & 79.20 & 87.77 & --- & -- \\
\hline $\mathbf{F}_{\mathbf{3}}\left(\mathbf{C}_{\mathbf{1}}\right)$ & 8.81 & 5.44 & 6.98 & 4.70 & 20.83 & 17.10 & 18.43 & 15.89 & 78.33 & 86.44 & 29.93 & 36.47 \\
\hline $\mathbf{F}_{\mathbf{4}}\left(\mathbf{C}_{\mathbf{2}}\right)$ & 6.67 & 10.58 & 6.95 & 6.19 & 10.75 & 14.85 & 9.11 & 11.36 & 71.93 & 58.48 & 90.88 & 89.48 \\
\hline
\end{tabular}

However, the realized heritability increased from $\mathrm{C}_{1}(29.93$ and $36.47 \%)$ to $\mathrm{C}_{2}(90.88$ and $89.48 \%)$ under normal and under water stress conditions, respectively. These results are in agreement with those obtained by Zakaria (2004), Ahmed (2006), Abd El-Kader (2011), Ali (2011), Mahdy (2012), Salous et al. (2014), Soliman et al. (2015) and Abd ElRady (2017).

2.2. Means and observed response under normal irrigation evaluation:

The two groups of selected families concerning high grain yield/plant for two cycles, either under normal irrigation or water stress were evaluated in the $\mathrm{F}_{4}$ generation under both environments and presented in Table 6. Grain yield of $\mathrm{F}_{4}$ families selected under normal irrigation and evaluated under normal irrigation ranged from $26.21 \mathrm{gm}$ for family No. 100 to $33.49 \mathrm{gm}$ for family No. 189 with an average of 29.71 gm/plant. The average direct observed gain from selection significantly $(\mathrm{P}<0.01)$ out-yielded the bulk sample by $40.29 \%$ and from the better parent by $29.92 \%$. Furthermore, all the selected families for grain yield/plant showed significant or highly significant observed gain from the bulk sample which was ranged from 23.69 to $58.14 \%$, eight of them, 
i.e., families No. 83, No. 122, No. 133, No. 170, No. 189 , No. 256 and No. 266 showed significant or highly significant observed gain of 27.60 , $23.64,24.47,46.13,27.18,46.45$, 46.44 and $26.93 \%$, respectively from the better parent.

The group of $\mathrm{F}_{4}$ families which selected for high grain yield/plant under water stress and evaluated under normal irrigation ranged from 23.29 for family No. 172 to 33.08 for family No. 196 with an average of 28.15 $\mathrm{g} /$ plant. The average direct observed gain from selection significantly $(\mathrm{P}<0.01)$ out-yielded the bulk sample by $32.89 \%$ and from the better parent $(\mathrm{P}<0.05)$ by $23.07 \%$. Furthermore, all the selected families except families No. 114 and No. 172 showed signifi- cant or highly significant observed gain from the bulk sample ranged from 21.85 to $56.19 \%$, six of them showed significant or highly significant observed gain from the better parent ranged from $22.34 \%$ for family No. 18 to $44.64 \%$ for family No.196.

\subsection{Correlated response under} normal irrigation evaluation:

Direct selection for high grain yield/plant for two cycles of selection under normal irrigation and evaluation under normal irrigation (Table 7) was accompanied by insignificant correlated response for days to heading $(-0.85 \%)$, days to maturity $(-0.95 \%)$, plant height $(4.94 \%)$ and number of kernels/spike (7.42\%).

Table 6. Mean grain yield/plant and observed gain from the bulk sample (OG\% Bulk) and from the better parent (OG\% BP) for the selected families after two cycles of selection for grain yield under normal irrigation and water stress conditions.

\begin{tabular}{|c|c|c|c|c|c|c|c|c|}
\hline \multirow{3}{*}{\multicolumn{2}{|c|}{ Item }} & \multirow{4}{*}{$\begin{array}{c}\text { Fam. No. } \\
83\end{array}$} & \multicolumn{6}{|c|}{ Environment of evaluation } \\
\hline & & & \multicolumn{3}{|c|}{ Normal irrigation } & \multicolumn{3}{|c|}{ Water stress } \\
\hline & & & Mean & OG\% Bulk & OG\% BP & Mean & OG\% Bulk & OG\% BP \\
\hline \multirow{22}{*}{ 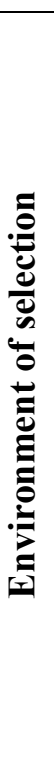 } & \multirow{11}{*}{ 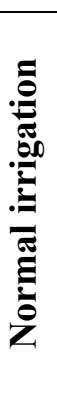 } & & 29.18 & $37.79 * *$ & $27.60 * *$ & 26.28 & $84.05 * *$ & $49.68^{* *}$ \\
\hline & & 100 & 26.21 & $23.69 *$ & 14.55 & 24.68 & $72.81 * *$ & $40.53^{*}$ \\
\hline & & 122 & 28.28 & $33.51 * *$ & $23.64 *$ & 19.27 & 34.96 & 9.76 \\
\hline & & 133 & 28.47 & $34.41^{* *}$ & $24.47^{*}$ & 23.22 & $62.61 * *$ & 32.23 \\
\hline & & 170 & 33.42 & $57.79 * *$ & $46.13 * *$ & 25.31 & $77.24 * *$ & $44.13^{*}$ \\
\hline & & 177 & 26.49 & $25.08^{*}$ & 15.84 & 23.36 & $63.56^{* *}$ & 33.01 \\
\hline & & 180 & 29.09 & $37.33 * *$ & $27.18 * *$ & 24.55 & $71.90 * *$ & $39.79 *$ \\
\hline & & 189 & 33.49 & $58.14 * *$ & $46.45 * *$ & 28.17 & $97.29 * *$ & $60.44 * *$ \\
\hline & & 256 & 33.48 & $58.12 * *$ & $46.44 * *$ & 21.68 & $51.80^{*}$ & 23.45 \\
\hline & & 266 & 29.03 & $37.06^{* *}$ & $26.93 * *$ & 21.02 & $47.18^{*}$ & 19.69 \\
\hline & & Mean & 29.71 & $40.29 * *$ & $29.92 * *$ & 23.75 & $66.34 * *$ & $35.27^{*}$ \\
\hline & \multirow{11}{*}{ 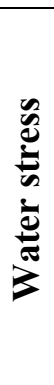 } & 2 & 30.04 & $41.85 * *$ & $31.36^{* *}$ & 20.11 & $40.83^{*}$ & 14.52 \\
\hline & & 5 & 31.16 & $47.12 * *$ & $36.25 * *$ & 15.82 & 10.78 & -9.91 \\
\hline & & 18 & 27.98 & $32.11 * *$ & $22.34^{*}$ & 23.45 & $64.19 * *$ & $33.53^{*}$ \\
\hline & & 56 & 28.18 & $33.05^{* *}$ & $23.22^{*}$ & 15.93 & 11.57 & -9.27 \\
\hline & & 99 & 31.58 & $49.10^{* *}$ & $38.08 * *$ & 19.73 & 38.14 & 12.34 \\
\hline & & 104 & 25.81 & $21.85^{*}$ & 12.84 & 18.59 & 30.16 & 5.85 \\
\hline & & 107 & 26.91 & $27.04 *$ & 17.65 & 23.51 & $64.61 * *$ & $33.87 *$ \\
\hline & & 114 & 23.44 & 10.66 & 2.48 & 23.09 & $61.67 * *$ & 31.47 \\
\hline & & 172 & 23.29 & 9.98 & 1.85 & 20.55 & $43.93 *$ & 17.04 \\
\hline & & 196 & 33.08 & $56.19 * *$ & $44.64 * *$ & 19.74 & 38.26 & 12.43 \\
\hline & & Mean & 28.15 & $32.89 * *$ & $23.07^{*}$ & 20.05 & $40.42 *$ & 14.19 \\
\hline & & Giza 171 & 22.87 & & & 17.56 & & \\
\hline & & Gemmiza11 & 21.00 & & & 16.96 & & \\
\hline & & $\begin{array}{l}\text { Bulk } \\
\end{array}$ & 21.18 & & & 14.28 & & \\
\hline \multicolumn{3}{|c|}{ R.LSD $_{0.05}$} & 4.36 & & & 5.74 & & \\
\hline \multicolumn{3}{|c|}{ R.LSD $_{0.01}$} & 5.77 & & & 8.34 & & \\
\hline
\end{tabular}


Table 7. Direct and correlated gains in the two cycles of selection for grain yield/plant in percentages from the bulk (OG\%"Bulk") and the better parent (OG\%"BP") under normal irrigation $(\mathrm{N})$ and water stress $(\mathrm{D})$ conditions.

\begin{tabular}{|c|c|c|c|c|c|c|c|c|c|c|}
\hline \multicolumn{3}{|c|}{ Item } & GY/P & DH & DM & PH & $\mathbf{N S} / \mathbf{P}$ & NK/S & $100 \mathrm{KW}$ & $\mathbf{B Y} / \mathbf{P}$ \\
\hline & \multicolumn{2}{|c|}{$\mathrm{F}_{3}$ families $\left(\mathrm{C}_{1}\right)$} & 14.25 & 92.67 & 139.51 & 104.94 & 6.95 & 37.01 & 5.55 & 52.29 \\
\hline & \multicolumn{2}{|c|}{ Giza $171(\mathrm{P} 1)$} & 11.59 & 95.33 & 141.33 & 99.90 & 6.15 & 36.58 & 5.28 & 45.72 \\
\hline & \multicolumn{2}{|c|}{ Gemmiza11(P2) } & 10.58 & 87.67 & 138.33 & 98.70 & 6.58 & 32.87 & 4.93 & 44.75 \\
\hline \multicolumn{3}{|c|}{ Bulk sample } & 10.99 & 93.67 & 140.33 & 99.03 & 6.02 & 35.01 & 5.11 & 45.66 \\
\hline \multirow{2}{*}{.} & \multicolumn{2}{|l|}{ OG\% (Bulk) } & $29.65 *$ & -1.07 & -0.58 & 5.97 & 15.47 & $5.70 * *$ & $8.51 *$ & 14.51 \\
\hline & \multicolumn{2}{|l|}{ OG\% (BP) } & 22.93 & $-2.80 *$ & -1.29 & 5.04 & 5.59 & 1.16 & 5.02 & 14.37 \\
\hline \multirow{2}{*}{$\Xi$} & \multicolumn{2}{|l|}{ R.LSD 0.05} & 3.11 & 2.21 & 4.20 & 7.57 & 9.07 & 1.28 & 0.40 & 16.31 \\
\hline & \multicolumn{2}{|c|}{ R.LSD $_{0.01}$} & 4.37 & 2.91 & 5.67 & 10.11 & 12.11 & 1.59 & 0.75 & 21.77 \\
\hline \multirow{2}{*}{\multicolumn{3}{|c|}{\begin{tabular}{|c|c}
$\mathrm{F}_{4}$ families & $\mathrm{I}$ \\
& $\left(\mathrm{C}_{2}\right)$
\end{tabular}}} & 29.71 & 105.43 & 153.53 & 117.57 & 10.62 & 50.68 & 5.52 & 95.66 \\
\hline & & & 28.15 & 105.90 & 155.37 & 116.71 & 10.45 & 50.74 & 5.33 & 80.36 \\
\hline & \multirow{3}{*}{\multicolumn{2}{|c|}{ Giza $171(\mathrm{P} 1)$}} & 22.87 & 106.00 & 156.33 & 115.60 & 9.13 & 49.30 & 5.14 & 77.25 \\
\hline & & & 21.00 & 107.00 & 153.67 & 115.00 & 9.09 & 46.57 & 4.96 & 76.71 \\
\hline & & & 21.18 & 106.33 & 155.00 & 112.03 & 8.68 & 47.18 & 5.09 & 67.40 \\
\hline & \multirow{2}{*}{ OG\% (Bulk) } & $\mathrm{N}$ & $40.29 * *$ & -0.85 & -0.95 & 4.94 & $22.40 *$ & 7.42 & $8.50 *$ & $41.94 * *$ \\
\hline & & $\mathrm{D}$ & $32.89 * *$ & -0.41 & $0.24^{*}$ & 4.18 & $20.35^{*}$ & 7.54 & $4.74 *$ & 19.23 \\
\hline & \multirow{2}{*}{$\mathrm{OG} \%(\mathrm{BP})$} & $\mathrm{N}$ & $29.22 * *$ & -0.53 & -0.09 & 1.71 & $16.37 *$ & 2.80 & $7.39 *$ & $23.84 *$ \\
\hline & & $\mathrm{D}$ & $23.07 *$ & -0.09 & 1.11 & 0.96 & $14.42 *$ & 2.92 & $3.66^{*}$ & 4.03 \\
\hline & \multicolumn{2}{|c|}{ R.LSD $_{0.05}$} & 4.36 & 2.40 & 2.72 & 8.04 & 1.30 & 7.48 & 0.050 & 18.34 \\
\hline & \multicolumn{2}{|c|}{ R.LSD $_{0.01}$} & 5.77 & 3.53 & 3.76 & 10.25 & 2.21 & 8.87 & 0.68 & 25.88 \\
\hline & \multicolumn{2}{|c|}{$\mathrm{F}_{3}$ families $\left(\mathrm{C}_{1}\right)$} & 13.65 & 91.42 & 138.36 & 98.20 & 6.44 & 42.11 & 5.08 & 50.78 \\
\hline & \multicolumn{2}{|c|}{ Giza $171(\mathrm{P} 1)$} & 9.64 & 89.00 & 139.33 & 95.00 & 5.90 & 37.21 & 4.80 & 43.47 \\
\hline & \multicolumn{2}{|c|}{ Gemmiza11 (P2) } & 8.74 & 88.33 & 136.33 & 96.88 & 5.18 & 35.85 & 4.71 & 42.54 \\
\hline & \multicolumn{2}{|c|}{ Bulk sample } & 8.75 & 87.67 & 136.00 & 96.58 & 5.27 & 34.16 & 4.50 & 32.63 \\
\hline & \multicolumn{2}{|l|}{ OG\% (Bulk) } & 55.97 ** & $4.28 * *$ & $1.73^{*}$ & 1.68 & $22.18^{*}$ & $23.26^{* *}$ & $12.78^{* *}$ & $55.61^{\text {*** }}$ \\
\hline & \multicolumn{2}{|l|}{ OG\% (BP) } & $41.57^{* *}$ & $2.72 *$ & -0.70 & 1.37 & 9.14 & 13.15 & $5.73^{*}$ & 16.81 \\
\hline & R.LSD $_{0.0}$ & & 2.31 & 2.40 & 1.90 & 4.59 & 1.15 & 6.11 & 0.27 & 11.13 \\
\hline שֶ & R.LSD $_{0.0}$ & & 3.16 & 3.47 & 2.60 & 6.01 & 149 & 7.90 & 0.48 & 14.59 \\
\hline & $\mathrm{F}_{4}$ families & $\mathrm{N}$ & 23.75 & 101.50 & 144.20 & 115.05 & 9.26 & 48.49 & 5.29 & 75.47 \\
\hline e & $\left(\mathrm{C}_{2}\right)$ & $\mathrm{D}$ & 20.05 & 102.20 & 142.87 & 115.02 & 8.69 & 47.37 & 4.89 & 64.40 \\
\hline & Giza 171 (P & & 17.56 & 103.00 & 146.33 & 110.20 & 7.35 & 47.89 & 5.02 & 63.73 \\
\hline & Gemmiza11 ( & & 16.96 & 102.33 & 144.67 & 107.80 & 7.23 & 47.89 & 4.93 & 51.33 \\
\hline & Bulk sample & & 14.28 & 100.33 & 142.33 & 108.87 & 6.60 & 47.67 & 4.86 & 61.93 \\
\hline & & $\mathrm{N}$ & $66.34 * *$ & 1.17 & 1.31 & $5.68 *$ & $40.37 * *$ & 1.72 & $8.76^{*}$ & 21.85 \\
\hline & $U$ & $\mathrm{D}$ & 40.42 & 1.86 & 0.38 & $5.65 *$ & $31.68^{*}$ & -0.62 & 0.62 & 3.98 \\
\hline & & $\mathrm{N}$ & $35.27^{*}$ & -1.46 & -1.46 & 4.40 & $28.09^{*}$ & 8.65 & $7.28 *$ & 47.02 \\
\hline & & $\mathrm{D}$ & 14.19 & -0.78 & -2.37 & 4.38 & $20.16^{*}$ & 6.15 & $-0.75 *$ & 25.46 \\
\hline & R.LSD $_{0.0}$ & & 6.18 & 2.51 & 3.41 & 5.89 & 1.31 & 9.16 & 0.074 & 20.70 \\
\hline & R.LSD $_{0.0}$ & & 8.38 & 3.32 & 4.74 & 8.57 & 2.46 & 12.73 & 1.03 & 28.75 \\
\hline
\end{tabular}

$\mathrm{N}=$ group selected under normal irrigation $\quad \mathrm{D}=$ group selected under water stress

$\mathrm{OG}=$ observed gain $\quad *$, ** significant at 5 and $1 \%$ levels of probability, respectively

However, positive and significant correlated gain was observed for number of spikes/plant $(22.40 \%)$, 100 -kernel weight $(8.50 \%)$ and biological yield/plant (41.94\%) and from the unselected bulk sample. Respect to the correlated gain from the better parent, significant positive correlated gain was recorded for number of spikes/plant (16.37\%), 100-kernel weight $(7.39 \%)$ and biological yield/plant (23.84\%), while insignifi- 
cant correlated gain was recorded for days to heading $(-0.53 \%)$, days to maturity $(-0.09 \%)$, plant height $(1.71 \%)$ and number of kernels/spike $(2.80 \%)$. Selection for high grain yield/plant for two selection cycles under water stress and evaluation under normal irrigation (Table 7) was accompanied by increase of 20.35 , $4.18,7.54,4.74$ and $19.23 \%$ for number of spikes/plant, plant height, number of kernels/spike, 100-kernel weight and biological yield/plant, respectively, compared to bulk sample. However, positive correlated gains for all studied traits from the better parent were obtained, except for days to heading $(-0.09 \%)$.

\subsection{Means and observed gains under water stress evaluation:}

The group of $\mathrm{F}_{4}$ families which selected for high grain yield/plant for two cycle under normal irrigation and evaluated under water stress ranged from 19.27 for family No. 122 to 28.17 for family No. 189 with an average of $23.75 \mathrm{~g} /$ plant (Table 6). The average direct observed gain from selection was highly significant (66.34\%) from the bulk sample while it was significant $(35.27 \%)$ from the better parent. Furthermore, nine selected families which selected for grain yield/plant showed significant or highly significant observed gain from the bulk sample ranged from 47.18 to $97.29 \%$, five of them, i.e., families No. 83, No. 100, No. 170, 180 and No. 189 showed significant or highly significant observed gain of $49.68,40.53,44.13,39.79$ and 60.44 $\%$, respectively from the better parent.

Mean of the group of $F_{4}$ families which selected for high grain yield/plant under water stress and evaluated under water stress ranged from 15.82 for family No. 5 to 23.51 for family No. 107 with an average of $20.05 \mathrm{~g} / \mathrm{plant}$. The average direct observed gain from selection, significantly $(\mathrm{P}<0.05)$ out yielded the bulk sample by $40.42 \%$. While the average direct observed gain from selection was insignificant (14.19\%) from the better parent. The four families No. 18 , No. 107 , No. 114 and No. 172 showed significant or highly significant observed gain of 64.19, 64.61, 61.67 and $43.93 \%$, respectively from the bulk sample, while the two families, No. 18 and No. 107 showed significant observed gain from the better parent.

2.5. Correlated response under water stress evaluation:

Selection for high grain yield/plant for two cycles of selection under normal irrigation and evaluation under water stress (Table 7) showed significant or highly significant correlated gain for plant height $(5.68 \%)$, number of spikes/plant $(40.37 \%)$ and 100 -kernel weight $8.76 \%$ ), while showed insignificant correlated gain for days to heading $(1.17 \%)$, days to maturity $(1.31 \%)$, number of kernels/spike $(1.72 \%)$ and biological yield/plant $(21.85 \%)$ than the bulk sample. Respect to the correlated gain from the better parent, significant positive correlated gain was recorded for 100-kernel weight $(7.28 \%)$ and number of spikes/plant (28.09\%), while insignificant correlated gain was recorded for days to heading $(-1.46 \%)$, days to maturity $(-1.46 \%)$, plant height $(4.40 \%)$, number of kernels/spike $(8.65 \%)$ and biological yield/plant (47.02\%). 
Direct selection for high grain yield/plant for two cycles of selection under water stress and evaluation under water stress was accompanied by significant increase for plant height $(5.65 \%)$ and number of spikes/plant (31.68\%); insignificant decrease for number of kernels/spike (-0.62\%) and insignificant increase for days to heading $(1.86 \%)$, days to maturity $(0.38 \%), 100$-kernel weight $(0.62 \%)$ and biological yield/plant (3.98\%) from the bulk sample. Direct selection for high grain yield/plant for two cycles of selection under water stress and evaluation under drought stress was accompanied by significant decrease for 100-kernels weight $(-0.75 \%)$; significant increase for number of spikes/plant (20.16\%) from better parent; insignificant decrease for days to heading $(-0.78 \%)$, days to maturity $(-2.37 \%)$ and insignificant increase for plant height $(4.38 \%)$, number of kernels/spike $(6.15 \%)$ and biological yield/plant (25.46\%) from better parent.

These results indicated that pedigree method of selection was effective in isolating high yield genotypes and the direct selection for grain yield per se was effective. Generally, it can be concluded that selection for high grain yield/plant for two cycles under normal irrigation was better than selection under drought stress either evaluation was practiced under normal irrigation or under drought stress. These results are in line with those reported by many investigators. Ismail (1995) reported that genetic gains in grain yield over the bulk sample and the better parent of 8.47 and 4.86 in a population and 6.96 and $6.41 \%$ in another popula- tion, respectively. El-Aref et al. (2014) came to the same previous conclusion. Kheiralla et al. (2006) after two cycles of selection for grain yield/plant achieved genetic gain of 20.21 and $7.62 \%$ from the bulk sample and the better parent, respectively. Ali (2011) indicated that pedigree selection for grain yield was effective in increasing grain yield. Our results are in contrast with results of Mahdy (2012) who reported that selection for high grain yield/plant for three cycles under drought stress was better than selection under normal irrigation either evaluation was practiced under normal irrigation or under drought stress. Also, Salous et al. (2014), Soliman et al. (2015) and Abd ElRady (2017) came to the same conclusion.

\subsection{Average observed gain} from selection for grain yield/plant in two cycles:

The observed gain from selection for high grain yield/plant under normal irrigation (Table 7) was 29.65 and $22.93 \%$ for cycle 1 and 40.29 and $29.22 \%$ for cycle 2 from the bulk sample and the better parent, respectively. The observed gain from selection for high grain yield/plant under water stress in the two cycles was 55.97 and $41.57 \%$ for cycle 1 and 40.42 and $14.19 \%$ for cycle 2 from the unselected bulk sample and the better parent, respectively. These results indicated that selection for high grain yield/plant under normal irrigation from the $\mathrm{F}_{4}$ generation was more effective than selection from $\mathrm{F}_{3}$. This may due to the increase of level of homozygosity in the $F_{4}$ generation, and it was easy to identify the genetically superior genotypes. Therefore, 
results suggest delaying selection for grain yield/plant to the $\mathrm{F}_{4}$ generation, till homozygosity reach acceptable level to save costs, effort and avoid loss of the best genotypes.

The second cycle selection was evaluated under both environments. The observed gain in normal irrigation group were (40.29 and 66.34\%) from bulk sample and (29.22 and $35.27 \%$ ) from the better parent compared to (32.89 and 40.42) from bulk sample and (23.07 and $14.19 \%)$ from the better parent for water stress group under normal irrigation and water stress, respectively. It is obvious that selection under normal irrigation was better than selection under water stress. In other words synergistic selection for grain yield was better than antagonistic selection.

\subsection{Drought susceptibility in- dex and sensitivity to environ- ments:}

The drought susceptibility index (DSI) and sensitivity to environments of the selected families for grain yield/plant are presented in Table 8 . The results of the selected families for two cycles under normal irrigation (normal group) when evaluated under both environments indicated that six families, i.e., No. 83, No. 100, No. 133, No. 177 , No. 180 and No. 189 showed drought susceptibility index (DSI) of $0.50,0.29,0.92,0.59,0.78$ and 0.79 , respectively. The six families which gave DSI less than one, gave also values less than one (less sensitive) in sensitivity test these families could be used as source of drought tolerance. Furthermore, it could be noticed that three superior families, No. 83, No. 180 and No. 189 were less susceptible and less sensitive to drought and showed significant observed gain over the better parent under normal irrigation and water stress these families could be promising families. The results of families which selected under drought stress and evaluated under both environments showed that, five families, No. 18, No. 104, No. 107, No. 114 and No. 172 gave drought susceptibility index of $0.56,0.97$, $0.44,0.05$ and 0.41 , indicating less susceptibility. Four of these families gave also values less than one in sensitivity test. It is of interest to indicate that the superior family, i.e., No. 18 was less susceptible and less sensitive to drought and showed significant observed gain over the better parent under normal irrigation and water stress. The mean sensitivity to drought of the selected families for high grain yield/plant under normal irrigation was 0.86 , while it was 1.17 for the selected families under deficit water (Table 8). 
Table 8. Drought susceptibility index (DSI) and sensitivity (S) to environments of selected families under normal irrigation and water stress after two cycles of selection for grain yield/plant.

\begin{tabular}{|c|c|c|c|c|c|c|c|c|c|}
\hline \multicolumn{10}{|c|}{ Environment of selection } \\
\hline \multicolumn{5}{|c|}{ Normal irrigation selections } & \multicolumn{5}{|c|}{ Water stress selections } \\
\hline Fam. No. & $\mathbf{N}$ & D & DSI & $\mathbf{S}$ & Fam. No. & $\mathbf{N}$ & D & DSI & $\mathbf{S}$ \\
\hline 83 & $29.18^{* *}$ & $26.28^{* *}$ & 0.50 & 0.42 & 2 & $30.04 * *$ & $20.11^{*}$ & 1.15 & 1.44 \\
\hline 100 & 26.20 & $24.68^{*}$ & 0.29 & 0.22 & 5 & $31.16^{* *}$ & 15.82 & 1.71 & 2.22 \\
\hline 122 & $28.28 *$ & 19.27 & 1.59 & 1.30 & 18 & $27.98^{*}$ & $23.45^{* *}$ & 0.56 & 0.66 \\
\hline 133 & $28.47^{*}$ & 23.22 & 0.92 & 0.76 & 56 & $28.18^{*}$ & 15.93 & 1.51 & 1.78 \\
\hline 170 & $33.42 * *$ & $25.31 *$ & 1.21 & 1.18 & 99 & $31.58^{* *}$ & 19.73 & 1.30 & 1.72 \\
\hline 177 & 26.49 & 23.36 & 0.59 & 0.45 & 104 & 25.81 & 18.59 & 0.97 & 1.05 \\
\hline 180 & $29.09^{* *}$ & $24.55^{*}$ & 0.78 & 0.66 & 107 & 26.91 & $23.51^{* *}$ & 0.44 & 0.49 \\
\hline 189 & $33.49 * *$ & $28.17^{*}$ & 0.79 & 0.77 & 114 & 23.44 & $23.09^{* *}$ & 0.05 & 0.05 \\
\hline 256 & $33.49 * *$ & 21.68 & 1.76 & 1.71 & 172 & 23.29 & $20.55^{*}$ & 0.41 & 0.40 \\
\hline 266 & $29.03 * *$ & 21.02 & 1.38 & 1.16 & 196 & 33.08 ** & 19.74 & 1.40 & 1.93 \\
\hline average & 29.71 & 23.75 & & 0.86 & Mean & 28.15 & 20.05 & & 1.17 \\
\hline Giza 171 & 22.87 & 17.56 & 1.16 & 0.77 & Giza 171 & 22.87 & 17.56 & 1.16 & 0.77 \\
\hline Gemmeiza11 & 21.00 & 16.96 & 0.96 & 0.59 & Gemmeiza11 & 21.00 & 16.96 & 0.96 & 0.59 \\
\hline Bulk & 21.18 & 14.28 & 1.62 & & Bulk & 21.18 & 14.28 & 1.62 & \\
\hline
\end{tabular}

$\mathrm{N}=$ normal irrigation

$\mathrm{D}=$ Water stress

$\mathrm{S}=$ sensitivity

* and **; significant observed gain from the better parent at 0.05 and 0.05 level of probability; respectively.

The relative merit after two cycles of selection for high grain yield was 0.82 when selection was under normal and water deficit and evaluation under normal irrigation, while it was 0.61 when selection was under normal and water deficit and evaluation under water stress.

These results indicate that the synergistic selection was better than antagonistic selection to increase grain yield/plant in these materials, either evaluation made under normal irrigation or under water stress. However, the synergistic selection reduced sensitivity to drought stress while, antagonistic selection increased it. These results were in contrasts with that found by Jinks and Connolly (1973 and 1975) on Schizophyllum Commune, Jinks and Pooni (1982) on Nicotiana rustica., Ceccarelli and Grando (1991 a and b) on barley and Mohamed (2001) on cotton. Falconer (1990) stated that, when selection and environment change the character in opposite direction this is antagonistic selection, i.e. selection upwards in a low environment or downwards in a high environment. Synergistic selection is the reverse; upwards in a high environment or downwards in a low environment, when selection and environment change the character in the same direction. Kheiralla et al. (2006) found that selection under early planting (synergistic selection) increased sensitivity of the selected families, while selection under late planting (antagonistic selection) decreased it. Mahdy (2012) found that the antagonistic selection was better than synergistic selection to increase grain yield/plant either evaluation made under normal irrigation or under drought stress and the antagonistic selection reduced sensitivity of the selected families, while the synergistic selection increased it.

2.8. The phenotypic correlation after two cycles of selection for grain yield/plant: 
The phenotypic correlations among traits after two cycles of selection for grain yield/plant under normal irrigation and water stress are shown in Table 9. After two cycles of selection the coefficients of phenotypic correlation under normal irrigation between grain yield/plant and each of days to heading, days to maturity, plant height, number of spikes/plant, number of kernels/spike, 100-kernel weight and biological yield/plant were $-0.308,-0.092$. $0.394,0.720,0.593,0.112$ and 0.757 , respectively. These results indicate that the most effective components in grain yield of wheat would be plant height, number of spikes/plant, number of kernels/spike and biological yield/plant. This means that, selection played on the highest correlated trait with grain yield/plant (plant height, number of spikes/plant, number of kernels/spike and biological yield/plant) in the base population.
The coefficients of phenotypic correlation under water stress were $0.171,0.101,0.348,0.651,0.518$, 0.393 and 0.832 between grain yield/plant and the above mentioned traits, respectively. These results indicated that selection under water stress decreased the correlation between grain yield and each of plant height, number of spikes/plant, number of kernels/spike and 100-kernel weight.

Positive genotypic correlation was recorded between yield and each of number of spikes/plant (Ahmed 2006, Sharma et al. 2006, Anawar et al., 2009) and biological yield/plant (khan et al. 2010, Moustafa, 2015 and Khames, et al. 2016). Mahdy (2012) indicated that high and positive phenotypic correlation between grain yield/plant and each of number of spikes/plant and biological yield/plant under normal irrigation and water stress.

Table 9. Phenotypic correlation among the studied traits for the $F_{4}$ generation under normal (above diagonal) and water stress (below diagonal) conditions.

\begin{tabular}{|c|c|c|c|c|c|c|c|c|}
\hline Trait & DH & DM & $\mathbf{P H}$ & $\mathbf{N S} / \mathbf{P}$ & $\mathbf{N K} / \mathbf{S}$ & $\mathbf{1 0 0 K W}$ & $\mathbf{G Y} / \mathbf{P}$ & $\mathbf{B Y} / \mathbf{P}$ \\
\hline DH & & $0.845^{* *}$ & -0.111 & -0.086 & -0.142 & $-0.300^{* *}$ & $-0.308^{*}$ & -0.215 \\
\hline $\mathbf{D M}$ & -0.011 & & 0.098 & 0.083 & -0.054 & $-0.249^{*}$ & -0.092 & -0.016 \\
\hline $\mathbf{P H}$ & -0.001 & 0.213 & & $0.249^{*}$ & $0.328^{*}$ & 0.061 & $0.394^{* *}$ & $0.459^{* *}$ \\
\hline $\mathbf{N S} / \mathbf{P}$ & 0.095 & 0.105 & 0.124 & & 0.066 & -0.165 & $0.720^{* *}$ & $0.699^{* *}$ \\
\hline $\mathbf{N K / S}$ & $-0.327^{* *}$ & -0.185 & 0.204 & -0.029 & & $-0.259^{*}$ & $0.593^{* *}$ & $0.223^{*}$ \\
\hline $\mathbf{1 0 0 K W}$ & -0.081 & $0.263^{* *}$ & $0.233^{* *}$ & 0.015 & -0.187 & & 0.112 & 0.145 \\
\hline GY/P & -0.171 & 0.101 & $0.348^{* *}$ & $0.651^{* *}$ & $0.518^{* *}$ & $0.393^{* *}$ & & $0.757^{* *}$ \\
\hline BY/P & 0.043 & $0.267^{* *}$ & $0.398^{* *}$ & $0.786^{* *}$ & $0.244^{*}$ & $0.285^{* *}$ & $0.832^{* *}$ & \\
\hline
\end{tabular}

\section{References}

Abd El-Kader, M.N.T. 2011. Selection for yield and some quality traits in durum wheat (Triticum turgidum var. durum). Ph.D. Thesis, Fac. Agric., Assiut Univ., Egypt.

Abd-El-Rady, A. G. 2017. Selection efficiency for grain yield under normal irrigation and water stress conditions in bread wheat. Assiut J. Agric. Sci., (48) No. (5) : (1-20). Ahmed, A.A.S., M.A. El-Morshidy, K.M. R.Kheiralla, R. Uptmoor, M.A. Ali and N.E.M. Mohamed. 2014. Selection for drought tolerance in wheat population (Triticum aestivum L.) by Independent culling levels. World J. Agric. Res. 2 (2): 56-62. 
Ahmed, T.A. 2006. Efficiency of late and early selection for grain yield under different selection criteria and DNA marker Polymorphism in wheat (Triticum aestivum L.). Assiut J. Agric. Sci. 37 (2): 1-16.

Ali, M.A. 2011. Pedigree selection for grain yield in spring wheat (Triticum aestivum L.) under drought stress conditions. Asian J. Crop Sci. 3 (4): 158-168.

Al-Jibouri, H.A., P.A. Miller and H.F. Robinson. 1958. Genotypic and environmental variance and covariance in an Upland cotton cross of interspecific origin. Agron. J. 50: 633-636.

Amin-Alim, M. 2011. The effects of water and heat stress on wheat. Agric. Trop. Et Subtropical 44 (1): 44-47.

Anwar, J.; M.A. Ali; M. Hussain; W. Sabir; M.A. Khan; M. Zulkiffal and M. Abdullah. 2009. Assessment of yield criteria in bread wheat through correlation and path analysis. The J. of Anim. \& Pl. Sci., 19: 185-188.

Attia, I.A. 2003. Selection for drought tolerance in wheat. $\mathrm{Ph}$. D. Thesis, El-Minia Univ., Egypt.

Betran, F.J., D. Beck, M. Banziger and G.O. Edmeades 2003. Genetic analysis of inbred and hybrid grain yield under stress and non stress environments in tropical maize. Crop Sci. J. 43 (3): 807-817.

Burton, G.W. 1952. Quantitative inheritance in grasses. Proceeding of $6^{\text {th }}$ International Grassland Congress, Vol. 1, Pennsylvania State College, 17-23 August 1952, 277-283.

Byrne P.F., J. Bolanos, G.O. Edmeades and D.L Eaton. 1995. Gains from selection under drought versus multiplication testing in related tropical maize populations. Crop Sci. J. 35 (1): 63-69.

Ceccarelli, S. and S. Grando. 1991a. Selection environment and environmental sensitivity in barley. Euphytica 57 (2): 157-167.
Ceccarelli, S. and S. Grando 1991b. Environment of selection and type of germplasm in barley breeding for low-yielding conditions. Euphytica 57 (3): 207-219.

Economic Affairs Sector, Ministry of Agricultural and Land reclamation, Egypt. Annual report. 2018.

El-Aref, Kh.A.O.; M.M. Ibrahim; M.S.H. Ahmad; A.M. Tammam and Y.S.I. Koubisy 2014. Selection efficiency and environmental sensitivity for grain yield in durum wheat under normal and heat stress conditions. Egypt. J. Appl. Sci., 29 (12): 682-696.

El-Rawi, K. and A.M. Khalafala. 1980. Design and Analysis of Agricultural Experiments. El-Mousel Univ. Iraq.

Falconer, D.S. 1989. Introduction to Quantitative Genetics. $3^{\text {rd }}$ ed. Longman, Hong Kong, pp 438.

Falconer, D.S. 1990. Selection in different environments: effects on environmental sensitivity (reaction norm) and mean performance. Genetical Research 56 (1): 57-70.

Fischer, R.A. and R. Maurer. 1978. Drought resistance in spring wheat cultivars. I. Grain yield response. Crop and Pasture Sci. 29 (5): 897912.

Ismail, A.A. 1995. Pedigree selection for grain yield, grain weight and earliness in two segregating populations of spring wheat. Assiut J. Agric. Sci. 24: 59-72.

Jinks, J.L. and H.S. Pooni. 1982. Determination of the environmental sensitivity of selection lines of Nicotiana rustica by selection environment. Heredity 49 (3): 291-294.

Jinks, J.L. and V. Connolly. 1973. Selection for specific and general response to environmental differences. Heredity 30: 33-40.

Jinks, J.L. and V. Connolly. 1975. Determination of environmental sensitivity of selection lines by the selection environment. Heredity 34 (3): 401-406. 
Khames, K.M., A. Abo-Elwafa, A.M. Mahmoud and A. Hamada 2016. Correlation, Path-coefficient, normal and stepwise regression analyses via two cycles of pedigree selection in bread wheat (Triticum aestivum L). Assiut J. Agric. Sci. 47:84-108.

Khan, A.J., F. Azam and A. Ali. 2010. Relationship of morphological traits and grain yield in recombinant inbred wheat lines grown under drought conditions. Pak. J. Bot., 42: 259-267.

Kheiralla, K.A. 1993. Selection response for grain yield and its components in a segregating population of spring wheat. Assiut J. Agric. Sci. 24:87-98.

Kheiralla, K.A., M.A. El-Morshidy, A.M. Tammam and M.M. Zakaria. 2006. The efficiency of selection and environmental sensitivity for grain yield in wheat. Symposium: Status and Improvement Horizons of Field Crops in the Arab World. 30-31 October, 2006, Alepo Univ., Syria.

Mahdy E.E., A.E. El-Karamity, S.A. Mokadem and H.M. Fouad 2012. Selection for grain yield and its components in two segregating populations. Minia Int. Conf. Agric. Irrig. In the Nile Basin Coun., $26^{\text {th }}-29^{\text {th }}$ March 2012, p. 595-604.

Mahdy, Rasha, E. 2012. Response to selection for earliness and yield in bread wheat under normal and drought conditions. Ph.D. Thesis, Fac. Agric. Assiut Univ., Egypt.

Mohamed, A. A. 2001. Breeding for earliness and yield components in some Egyptian cotton crosses. $\mathrm{PhD}$. Thesis Fac. Agric. Assiut Univ. Assiut, Egypt.

Moustafa, H.M.F, 2015. Single and multiple traits selection in bread wheat under normal and drought stress conditions. Ph.D. Thesis, Fac. Of Agric., Minia Univ., pp. 166.

Passioura, J. 2007. The drought environment: physical, biological and agricultural perspectives. J. Exp. Bot. 58 (2): 113-117.

Rathjen, A.J. 1994. The biological basis of genotype environment interaction Its definition and management. In Proceedings of the Seventh Assembly of the Wheat Breeding Society of Australia, Adelaide, Australia.

Salous, M.SH., M.A. El-Morshidy, K.A. Kheiralla and M.Kh. Moshref. 2014. Selection for grain yield in bread wheat (Triticum aestivum L.) Under normal and heat stress conditions. Assiut J. Agric. Sci. 45:118.

Sharma, V., I.S. Pawar and R. Munjal. 2006. Variability parameters, correlation and path coefficients for yield, its components and quality traits in bread wheat. Nat. J. P1. Improv., 8: 153-155.

Soliman G.M.M., M.A. El-Morshidy, K.A. Kheiralla and I.A. Amin. 2015. Selection efficiency under both normal irrigation and water deficit conditions in durum wheat. Egypt. J. Agric. Res. 93 (2): 335 351.

Steel, R.G.D. and J.H. Torrie. 1980. Principle and Procedures of Statistics. A Biometrical approach $2^{\text {nd }}$ Ed., McGraw-Hill Book Company, New York. U.S.A.

Tammam, A.M., M.S.F. El-Ashmoony, A.A. El-Sherbeny and I.A. Amin. 2004. Selection responses for drought tolerance in two bread wheat crosses. Egypt J. Agric. Res. 82 (3): 1213-1226.

Walker, T.T. 1960. The use of a selection index technique in the analysis of progeny row data. Emp. Cott. Rev. 37: 81-107.

Zakaria, M.M. 2004. Selection for earliness and grain yield in bread wheat (Triticum aestivum L.) under different environmental conditions. Ph.D. Thesis, Fac. of Agric. Assiut Univ., Egypt. 
الاتتخاب لمحصول الحبوب تحت ظروف الري العادي و الإجهاد المائي في قمح الخبز

\section{ياسر سيد إبر اهيم قبيصي}

قسم بحوث القمح ـ معهد بحوث المحاصيل الحقلية ـ مركز البحوث الزر اعية

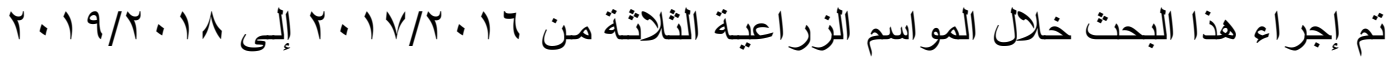

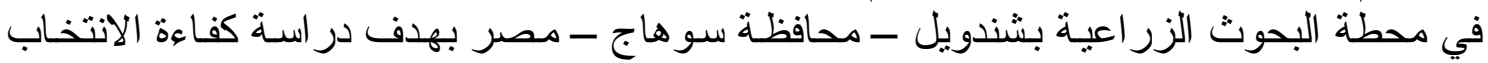

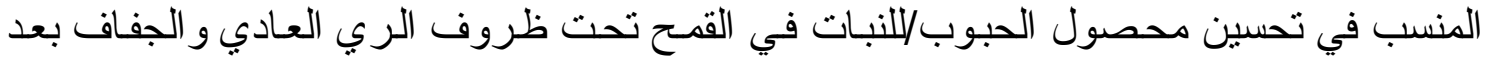

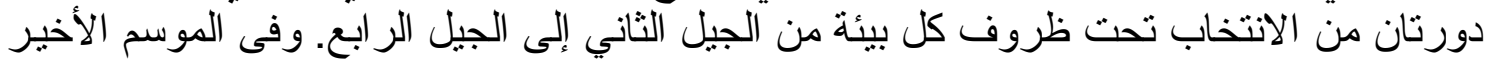

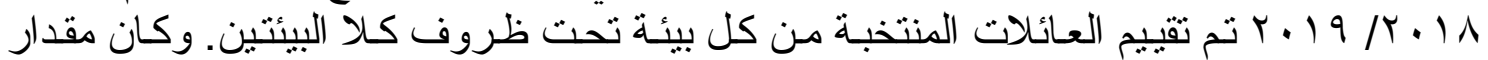

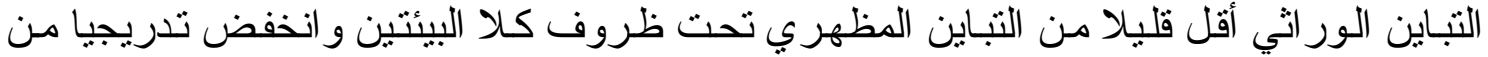

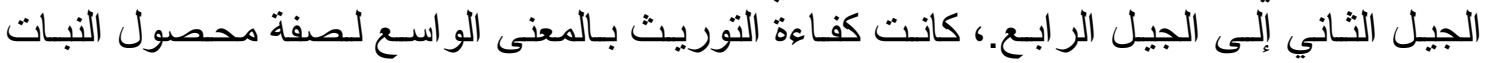

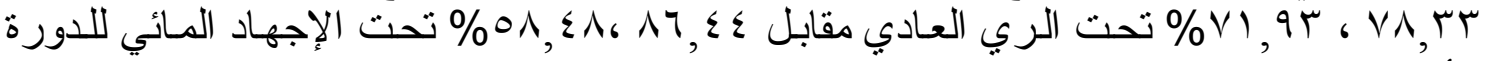

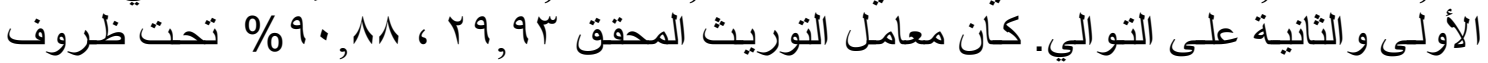

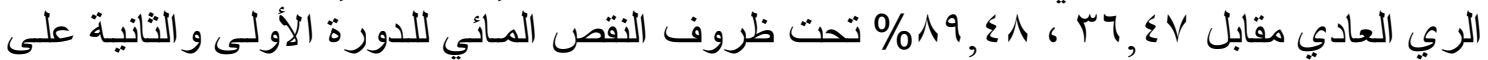

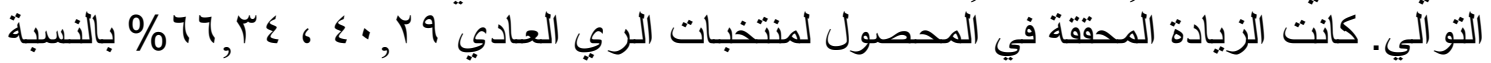

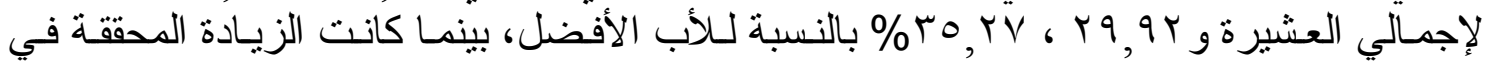

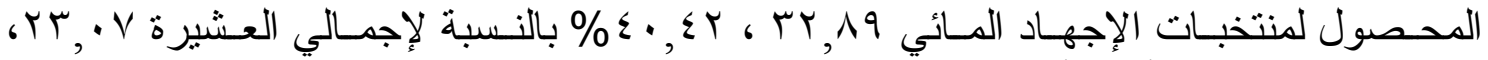

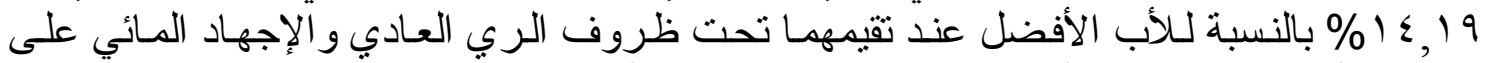

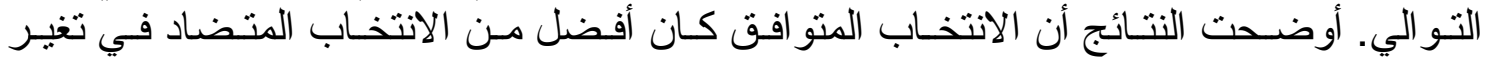

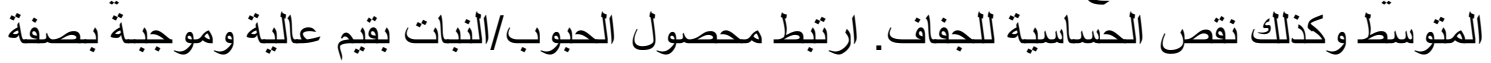

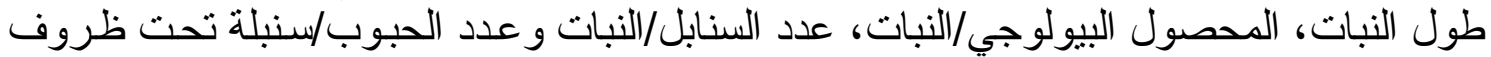

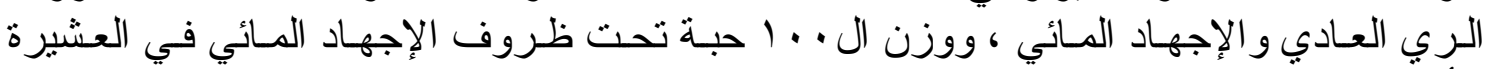
الأساسية وبعد دورتين من الانتخاب لمحصول الحبوب/الإبنات. 